\title{
Adventures and excursions in bioassay-the stepping stones to prostacyclin
}

\author{
J. R. VANE \\ F.R.S. \\ Wellcome Research Laboratories, Langley Court, Beckenham, Kent
}

Physiology has spawned many biological sciences, amongst them my own field of pharmacology. No man has made a more important contribution to the fields of physiology and pharmacology than Sir Henry Dale (1875-1968, Nobel Laureate in Physiology and Medicine in 1936). Dale had a great influence not only on British pharmacology in general but also on my own scientific endeavours. Indeed, I can put forward a strong case for considering myself as one of Dale's scientific grandchildren. My early days as a pharmacologist were influenced not only by Dale himself but also by his own school of colleagues, including Burn, Gaddum and von Euler. It was Burn who taught me the principles and practice of bioassay. Some of Gaddum's first publications were on the development of specific and sensitive methods for biological assay and he maintained a deep interest in this subject for the rest of his life (1). In 1964 he said "the pharmacologist has been a 'jack of all trades' borrowing from physiology, biochemistry, pathology, microbiology and statistics - but he has developed one technique of his own, and that is the technique of bioassay" (2).

Expensive, powerful and sophisticated chemical methods, such as gas chromatography and mass spectrometry, have been developed and perfected for detection and quantification of prostaglandins (PGs) and related substances. One should not forget, however, that starting with the discovery and isolation of prostaglandins by von Euler [3; see also Bergström (1983)†], biological techniques and bioassay have contributed very substantially to the development of the field. Bioassay has provided crucial information on the role of the lungs in the removal of circulating prostaglandins (4), the partici-

(c) The Nobel Foundation 1983.

Dr John Vane delivered the Francis Fraser lecture at the Academic Assembly of the British Postgraduate Medical Federation on 3rd June 1983 on the subject of 'Prostacyclin-from discovery to the clinic'.

†Bergstrom, S. (1983) Lecture to be published in 'Les Prix Nobel 1982'. Nobel Foundation (in press). pation of prostaglandins in inflammatory reactions $(5,6)$, the contribution of prostaglandins to the autoregulation and maintenance of blood flow to the kidney (7-9), the inhibitory effect of aspirin-like drugs on the biosynthesis of prostaglandins (10-12), the mediation of pyrogen fever by prostaglandins (13), and the release of rabbit aorta-contracting substance (RCS; now identified as thromboxane $A_{2}$, TXA $_{2}$ ) from lungs during anaphylaxis $(14,15)$. Moreover, in 1976, bioassay made possible the discovery of PGX, now renamed prostacyclin $\left(\mathrm{PGI}_{2}\right)$, the latest member of the prostaglandin family (16-19). Indeed, it is doubtful whether the biological significance of any of the unstable products of arachidonic acid metabolism would have been recognised without bioassay techniques. With extraordinary simplicity and convenience, by its very nature, bioassay distinguishes between the important biologically active compounds and their closely related but biologically unimportant metabolites.

In this review I shall discuss the development of the cascade superfusion bioassay technique and some of the discoveries and concepts which arose from its application, leading up to the discovery and development of prostacyclin. The effects of prostacyclin in man and its clinical assessment (another application of bioassay) will also be discussed.

\section{Cascade superfusion bioassay}

\section{(a) Development}

Most uses of bioassays involving smooth muscle demand high sensitivity and specificity. These aspects have been achieved, first by limiting the volume of fluid bathing the isolated tissue and, second, by using an assay organ sensitive to, and relatively specific for, the test substances under study. Further specificity can be achieved by using a combination of several tissues which present a characteristic pattern of response to the test substance or substances. This 


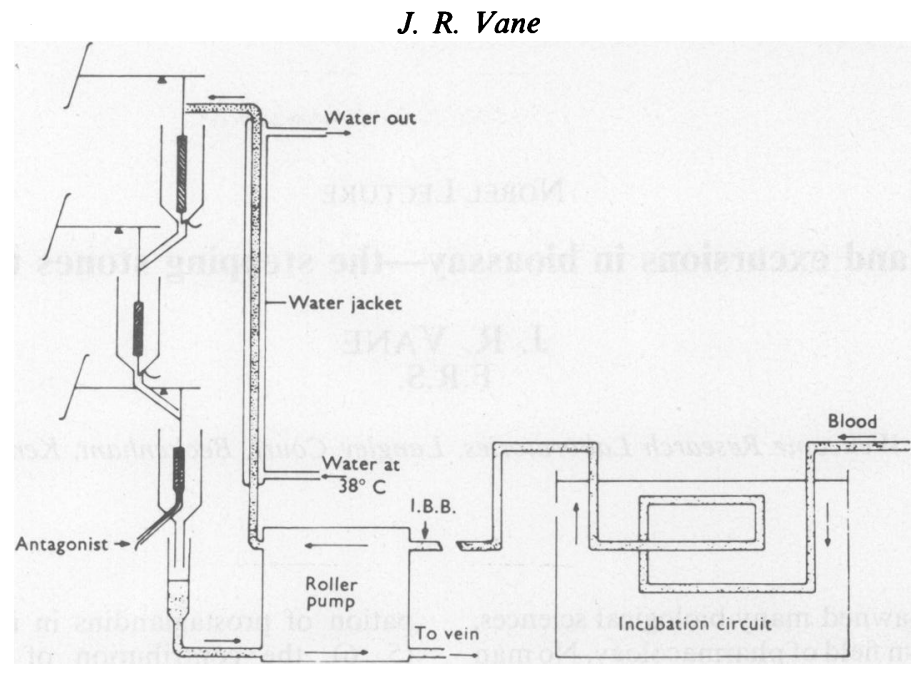

FIG. 1. Diagram of the blood-bathed organ technique. Blood is continuously withdrawn from a convenient vessel by a roller pump, kept at $37^{\circ} \mathrm{C}$ by a water jacket and then allowed to superfuse a series of isolated organs, the longitudinal movements of which are recorded. The blook is then collected in a reservoir and returned to the animal. In some experiments, the blood flows through a length of silicone tubing in a wates bath (incubating circuit) before superfusing the isolated tissues. Drugs can be applied directly to the isolated tissues by infusions or injectiong into the bathing blood (I.B.B.) or with a time delay into the incubating circuit (from Vane 1969, reference 33, by permission of The Macmillant Press Ltd).

takes advantage of the principle of parallel pharmacological assay, regarded by Gaddum (20) as strong evidence for the identity of a compound.

Magnus (21) introduced the idea of suspending an isolated portion of smooth muscle in a chamber containing a nutrient fluid and measuring changes in tissue tone. The organ baths used today are modified versions of that used by Dale (22). Gaddum (23) applied the experimental design developed by Finkleman (24) to the assay of minute amounts of biologically active substances. He called his technique 'superfusion' in contrast to perfusion. This consisted of bathing an assay tissue with a stream of fluid which was momentarily stopped at the moment of addition of the test substance. Vane (25) introduced the idea of superfusing several tissues in cascade (generally up to six, arranged in two banks) (Fig. 1). Besides being useful for the parallel assay of individually injected samples, this arrangement also allows parallel analysis of the active components present in a fluid stream (most commonly Krebs' solution) taken from the outflow of a perfused organ.

Another innovation introduced by Vane (25) was to use blood as the superfusion medium (the bloodbathed organ technique). The anaesthetized animal is heparinized and blood is continuously removed at a constant rate of $10-15 \mathrm{ml} / \mathrm{min}$ (dogs, cats and rabbits). Lower rates can be used from guinea-pigs (26). The blood (either from a vein or from an artery) superfuses the assay tissues and is then returned by gravity to a large vein.
Plainly, when perfusate from an organ or bloof from an animal is used for superfusion, substagce can reach the assay tissues within a few second of generation or release. This element of 'instantarfity' is an important aspect of cascade superfusion bions say in that it detects the biological activity chemically unstable compounds whose activity would otherwise be lost in an extraction process. Another important feature of the method is that ot gives the maximum opportunity for serendipity. The dynamic nature of the assay also allows the measurement of inactivation of an infused substance across $\overline{3}$ particular vascular bed. Further modifications of the bioassay technique have been developed by Collier (27), Ferreira and Souza Costa (28) and Gryglewski and colleagues (29).

\section{(b) Choice of bioassay tissues}

It is usually possible to find a piece of smoot muscle which is particularly sensitive to the hormone under investigation and relatively insensitive to other. substances. Indeed, think of any part of the body and you can be sure that the pharmacologist has cut-it out, put it into an isolated organ bath, or perfused 遏 vessels in order to study the effects of drugs. Fot bioassay, segments of the gastrointestinal tract or spirally-cut strips of vascular tissue have mainly been used. Such procedures are the backbone not only of bioassay but also of classical pharmacology.

Fig. 2 depicts the reactions of some superfused 


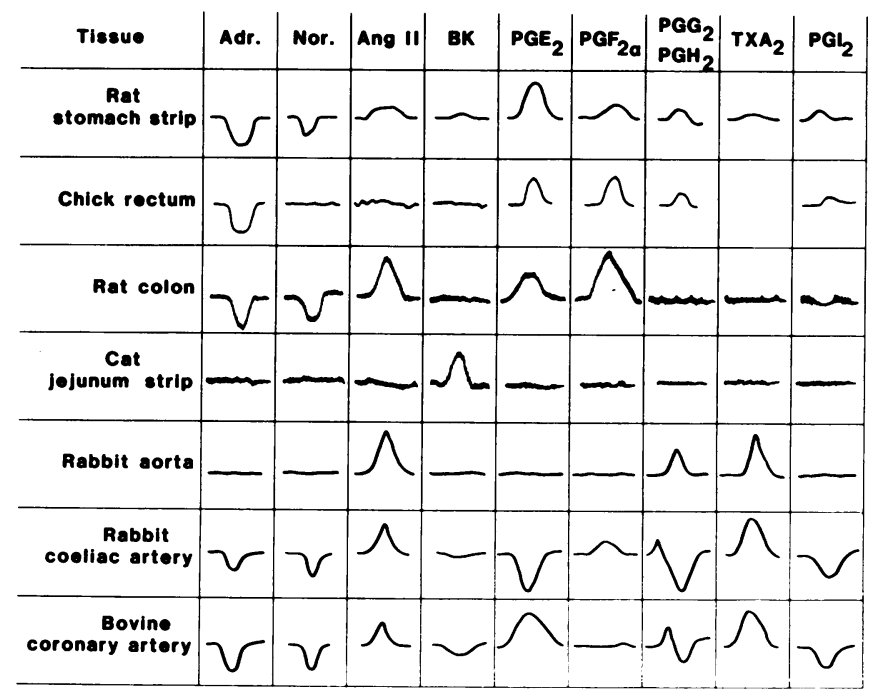

FIG. 2. Diagram showing the reactions of some blood-bathed organs to various endogenous substances in concentrations of $0 \cdot 1-5 \cdot 0 \mathrm{ng} / \mathrm{ml}$. The actions of the catecholamines can be abolished by treatment with suitable blocking agents.

isolated tissues to various endogenous substances in concentrations likely to be found in circulating blood. It should be remembered that when blood is used as the superfusing medium, some smooth muscle preparations (but not others) exhibit an increased resting tone often lasting for the duration of the experiment. Such increased tone reduces sensitivity to substances which cause contraction but increases sensitivity to those which induce relaxation.

For detection of the classical prostaglandins, the most useful combination of assay tissues is the rat stomach strip, rat colon and chick rectum. For PG endoperoxides and later for prostacyclin, vascular tissues were added such as strips of coeliac or mesenteric artery (30). Strips of bovine coronary artery (31) were especially useful for they contracted to $\mathrm{PGE}_{2}$ but relaxed to prostacyclin (Fig. 2).

The specificity of a bioassay can be increased still further by the use of antagonists. For instance, contractions of the rat stomach strip induced by 5hydroxytryptamine can be abolished by a specific antagonist such as methysergide, thereby leaving the preparation more specifically sensitive to the prostaglandins. The rat colon is relaxed by catecholamines but contracted by angiotensin II; when both are present in the superfusion fluid, the catecholamines reduce the contraction produced by angiotensin. This unwanted interference is prevented by blocking the actions of catecholamines with a $\beta$-receptor antagonist. When blood is used as the superfusion fluid, the antagonist can be perfused through the closed lumen (Fig. 1) of, say, the rat colon (32) thus localizing the blocking agent to the assay tissue and minimizing its effects on the whole animal. For a detailed discussion of the limitations of the cascade superfusion bioassay technique, the reader is referred to Vane (33) and Moncada, Ferreira and Vane (34).

(c) Measurement of substances by cascade superfusion bioassay

The technique is well suited for measuring substances released into the circulation, such as catecholamines or angiotensin II, and also for determining the fate of substances released or infused into different parts of the circulation.

(i) Release of substances in response to stimuli. Release of catecholamines from the adrenal medulla can be detected and quantitated by use of a rat stomach strip and chick rectum. This technique was used to demonstrate that circulating catecholamines appeared to play little or no part in arterial baroreceptor reflexes (25) and also that catecholamines are released into the circulation during anaphylaxis (35). Of the substances released during the anaphylactic reaction, histamine, bradykinin and slow reacting substance in anaphylaxis (SRS-A) will all in turn release adrenaline when injected intravenously, although there may be species differences in the mechanisms of action and in the sensitivity of the adrenal medulla (36-38).

An early use of the blood-bathed organ technique was to show the sequential release of angiotensin II and catecholamines during haemorrhage (39). Release of bradykinin into the blood stream by the intravenous injection of kallikrein or by contact of the blood with glass was easily demonstrated (40) but 


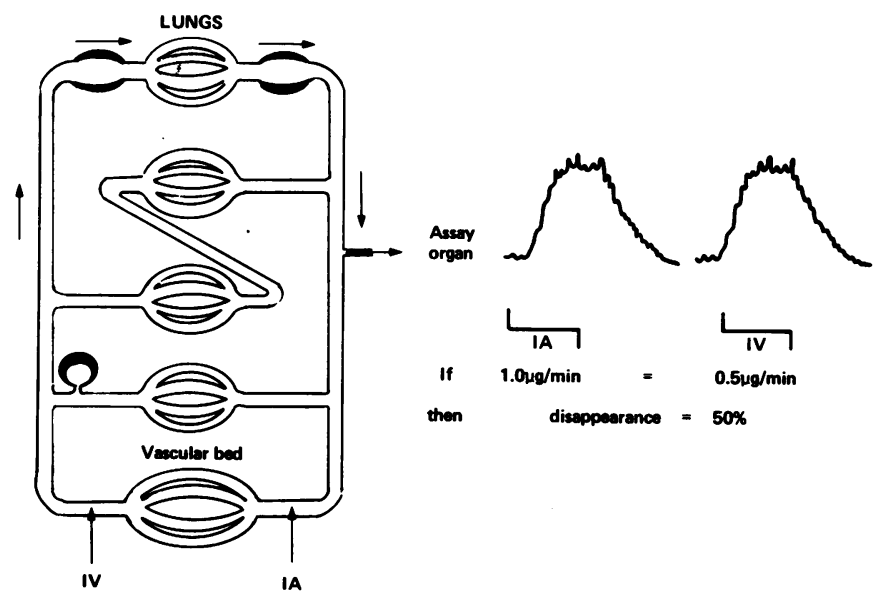

FIG. 3. Diagram showing principle of bioassay of the degree of disappearance across a vascular bed. The differences in responses of the blood' bathed organs to infusions made i.a. or i.v. represent the degree of removal of the substance in one passage through the vascular bed. $\infty$

we consistently failed to demonstrate with this technique the endogenous release of bradykinin by physiological manipulation. However, circulating kinins were demonstrated during hypotension due to haemorrhage in the dog and the concentrations detected in the bloodstream were sufficient to lower a normal blood pressure (41).

(ii) Inactivation of circulating vasoactive substances. By comparing the effects on the blood-bathed assay organs of infusions of a substance over several minutes into a particular vascular bed with the effects of similar infusions given into the effluent of the vascular bed, it is possible to assay the percentage of the substance disappearing in one circulation through that vascular bed (Fig. 3). This technique allowed the demonstration of the inactivation of several vasoactive substances as they passed through vascular beds such as the hind legs, the liver and the lungs.

Angiotensin II, for example, is unaffected by passage through the pulmonary circulation, either in vivo or in isolated lungs of all species studied, including rats, dogs, guinea-pigs, cats and man (for review see Bakhle and Vane, 42). However, the same substance is substantially inactivated $(50-70 \%)$ in one passage through peripheral vascular beds such as the liver, the kidneys and the hind legs (43).

We also studied the fate of adrenaline and noradrenaline and found in both cats and dogs that $70-95 \%$ of an intra-arterial infusion of adrenaline or noradrenaline disappeared in one passage through the hind quarters. The lungs, however, inactivated up to $30 \%$ of an infusion of noradrenaline without interfering with the passage of adrenaline $(44,45)$.

Bradykinin is fairly rapidly destroyed in blood and has a half-life in the blood stream of cat or dog $\frac{\vec{\sigma}}{\mathrm{f}}$ about $17 \mathrm{sec}$. Ferreira and Vane (46) showed that whereas the liver inactivated about $50 \%$, the lungs inactivated about $80 \%$ of the bradykinin infusion.

It was observations such as these that drew orf attention to the metabolic and pharmacokinete function of the pulmonary circulation. The selectivi of the pulmonary inactivation mechanism is stoik. ingly demonstrated by the way in which the lungs inactivate bradykinin but allow other peptides sī. ch as eledoisin, substance $P$, physalaemin, vasopress and oxytocin to pass through without change (42).

The metabolism of prostaglandins in the pulmक्ष nary circulation in vivo was first studied by Vane an his colleagues $(4,47)$ who showed that almost all an infusion of $\mathrm{PGE}_{1}, \mathrm{PGE}_{2}$ or $\mathrm{PGF}_{2 \alpha}$ was inactivated in one passage through the lungs. McGiff et al. (48) confirmed that $\mathrm{PGE}_{1}$ and $\mathrm{PGE}_{2}$ were avidly removed by dog lung in vivo but further showed that $\mathrm{PGA}_{1}$ and $\mathrm{PGA}_{2}$ survived the passage through the lungs without change. Thus, within this very closely related grou of substances, the inactivation process can distinguisti between the individual members. Interestingly, aftẹ. the discovery of prostacyclin, we also found (49) that prostacyclin (unlike $\mathrm{PGE}_{1}$, see Fig. 4) survived passage through the pulmonary circulation without change. In other vascular beds, the inactivation of prostacyclin in a single passage (50-70\%) was con parable to that of $\mathrm{PGE}_{2}$. Thus, the hind quarters, ang particularly the liver, removed some of the prosta cyclin which reaches those beds.

Overall, the inactivation of prostacyclin in onf circulation was about $50 \%$ giving a metabolic half life of one circulation time $(c .30 \mathrm{sec})$ as compareg with the chemical half life of 2-3 min. The inactive tion mechanisms of $\mathrm{PGE}_{2}$ and prostacyclin (50) are similarly dependent on PG 15-hydroxydehydrogeno 

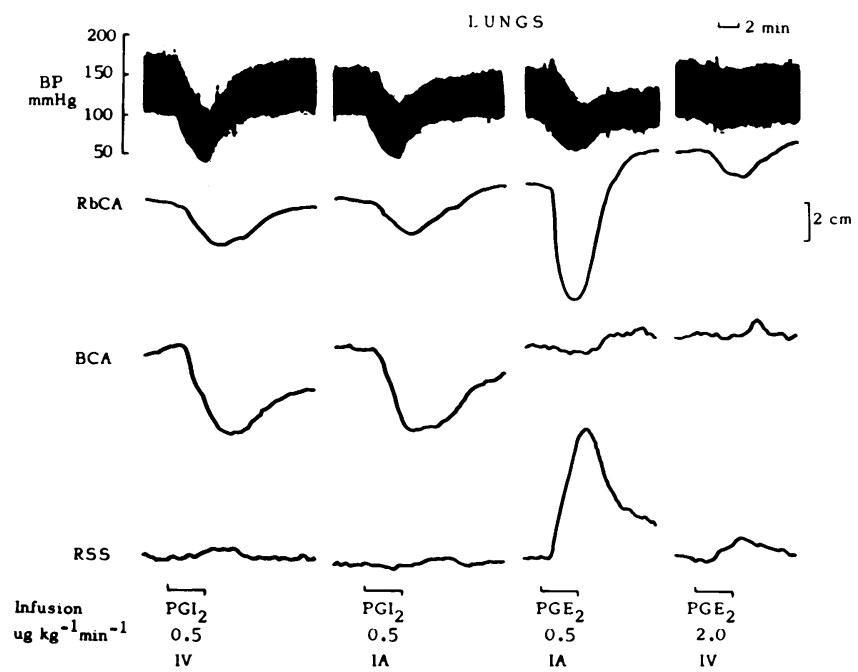

FIG. 4. Passage of prostacyclin $\left(\mathrm{PGI}_{2}\right)$ and prostaglandin $\mathrm{E}_{2}\left(\mathrm{PGE}_{2}\right)$ across the lungs. Spiral strips of rabbit coeliac artery (RbCA), bovine coronary artery (BCA) and rat stomach strip (RSS) were bathed in arterial blood from a dog. $\mathrm{PGI}_{2}$ infused intravenously (IV) caused similar

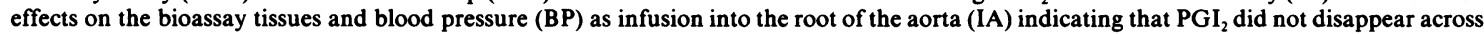
the lungs. In contrast, much more than $75 \%$ of $\mathrm{PGE}_{2}$ was inactivated in passage through the pulmonary circulation. (From Dusting, Moncada and Vane, 1978 reference 49, by permission of The Macmillan Press Ltd).

ase, (PGDH). However, the disappearance of prostaglandins in the pulmonary circulation depends on two mechanisms, namely uptake and enzyme attack by PGDH, so our results suggested that prostacyclin is not a substrate for the PG uptake mechanism.

From the differential removal of vasoactive hormones by the pulmonary circulation, we proposed that they could be divided into at least two types'local' and 'circulating' hormones. The local hormones are those which are largely removed by the lungs and if they have a physiological function, it is probably localized at or near to the site of release. It is intriguing to think that venous blood may be full of potent, as yet unidentified, chemicals released by peripheral vascular beds but removed by the lungs before they can cause effects in the arterial circulation. Interestingly, in 1970, Gryglewski and Vane described the release of an unidentified substance into the venous blood after infusion of isoprenaline into the hind legs of dogs (51). The pattern of activity of this substance on the blood-bathed assay tissues was unlike that of any prostaglandin known at that time, but it can now be clearly identified as prostacyclin.

Circulating hormones are those which pass through the lungs, either unchanged (adrenaline, histamine, vasopressin, prostacyclin) or with an actual increase in activity. One such demonstration of an increase in activity on passage through the pulmonary circulation was associated with the reninangiotensin system. We showed (52) that, contrary to popular belief, conversion of angiotensin I to angio- tensin II did not take place in the bloodstream, but was largely accomplished in the pulmonary circulation. This was demonstrated both in vivo (52-54) and in vitro (Fig. 5).

(iii) Our studies of substances released during anaphylaxis. Piper and Vane $(14,55,56)$ made a series of studies in which they investigated the release of mediators from perfused lungs isolated from sensitised guinea-pigs. We found, as expected, that there was a large release of histamine when the lungs were challenged with antigen. As also expected, we found a release of SRS-A. However, we were excited at that time to find the release of three other substances which had not previously been associated with anaphylaxis (Fig. 6). We detected the release of prostaglandin-like substances with our bioassay system and were later able to show by thin-layer chromatography that prostaglandins $\mathrm{E}_{2}$ and $\mathrm{F}_{2 \alpha}$ were present in the effluent. Even more exciting was the detection of the release of a previously undescribed substance which caused a strong contraction of strips of rabbit aorta and which we called, because of this effect "rabbit aorta contracting substance" or RCS. Two operations of RCS intrigued us. First, it was chemically unstable and if we introduced a delay coil of a few minutes before the lung effluent reached the assay tissues the activity had disappeared, although that of histamine, PGE $_{2}$, PGF $_{2 \alpha}$ and SRS-A was still present. Second, we found that the release of RCS during anaphylaxis was selectively prevented by aspirin and other similar compounds. Piper and Vane (14) postulated that RCS may be involved in causing 


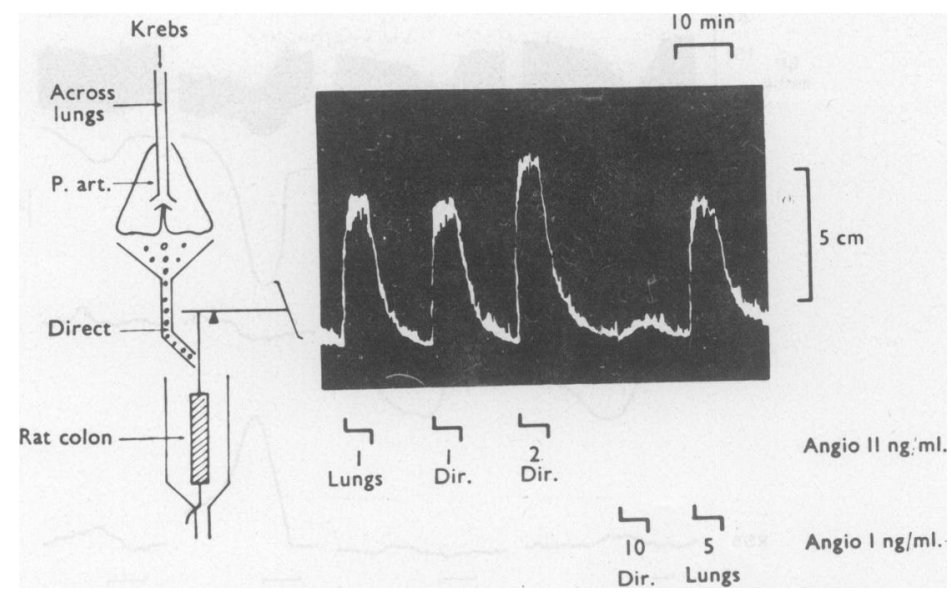

FIG. 5. Increased activity of angiotensin I when passed through guinea-pig isolated lungs. The diagram on the left shows the experimentag procedure. Infusions of angiotensin II (Angio II) through the lungs or direct to the rat colon (Dir.) gave the same response of the rat colongo showing that there was no destruction in the lungs. An infusion of angiotensin I (Angio I) at $10 \mathrm{ng} / \mathrm{ml} \mathrm{direct} \mathrm{to} \mathrm{the} \mathrm{rat} \mathrm{colon} \mathrm{gave} \mathrm{a} \mathrm{minimak}$ response, but when half this concentration $(5 \mathrm{ng} / \mathrm{ml})$ was infused through the lungs there was a much greater contraction of the rat colon $\vec{\epsilon}$ Time, $10 \mathrm{~min}$, vertical scale $5 \mathrm{~cm}$. (From Vane, 1969, reference 33, by permission of The Macmillan Press Ltd).

those symptoms which aspirin relieves. Isolated lungs also released prostaglandins into the perfusate when particles (up to $120 \mu \mathrm{m}$ ) were infused into the pulmonary artery (57).

At this time, we were also becoming interested in prostaglandin release from other tissues. Mammalian cells of all types disgorge prostaglandins at the slightest provocation, but the tissue content of prostaglandins is very low compared with the release. This is well-illustrated in the dog spleen, from which less than $1 \mu \mathrm{g}$ (or $7 \mathrm{ng}$ per $\mathrm{g}$ wet weight) can be extracted; however, the spleen can release up to $10 \mu \mathrm{g}$ of prostaglandin (assayed as $\mathrm{PGE}_{2}$ ) per min when it is stimulated. Horton and his colleagues (58) were the first to demonstrate that $\mathrm{PGE}_{2}$ was released into splenic venous blood following splenic nerve stimulation in the dog. We became interested in the characteristics of the release and further showed that the output $\left(\mathrm{PGE}_{2}\right.$ and $\left.\mathrm{PGF}_{2 \alpha}\right)$ was associated with contraction of the spleen, for it could be induced by adrenaline and prevented by $\alpha$-adrenoreceptor antagonists. Interestingly, as in the lungs, we found that prostaglandins were released by the spleen in response to infusions of particles (59).

\section{Aspirin and prostaglandin biosynthesis}

In research there is always a 'climate' of experience which acts as a background to important discoveries. I have tried to indicate the 'climate' in our laboratory at the Royal College of Surgeons of England around the year 1970. We had a major interest in the release and fate of vasoactive hormones and were pursuing this with special reference to the lungs. We had discovered RCS as an unstable substance released from lungs during anaphylaxis and we knew that it release was inhibited by aspirin and other aspirin-lik\& drugs. We had become interested in the prostaglan dins and had come to the idea that any tissue which was distorted or disturbed or traumatized wogld release prostaglandins. In this context, it seemesto me that each distention of the lungs might caus a prostaglandin release which could help to adjust the regional pulmonary blood flow. Indeed, the idea tha a prostaglandin release might be important in cono trolling regional blood flow in the lungs had also been suggested by Liljestrand (60). With overe distention, any prostaglandins released might $\vec{b} \vec{E}$ detected in the arterial blood stream. I started a series of experiments using the blood-bathed organ tech? nique to test this hypothesis. In anaesthetized dogs, 需 was easy to show that when they were hyperventis lated, there was an output into the arterial bloos from the pulmonary circulation of an RCS-like substance and of $\mathrm{PGE}_{2}$ and $\mathrm{PGF}_{2 \mathrm{a}}$ (Vane, unpublished). It was at this time that I was impressed by the effects of an infusion of aspirin into the hypervent ${ }^{2}$ lated dog, for not only was the associated hypoteng sion reduced, but there was also a strong inhibition of the prostaglandin release. It was this experiment that led me to the idea (over a weekend) that aspirin might be interfering with prostaglandin biosynthesis. On the Monday morning I said to Sergio Ferreir岱 and Priscilla Piper "I think I know how aspirity works" and set about doing an experiment. Anggard and Samuelsson (61) had described a preparation of guinea-pig lungs in which a crude cell-free homogen ate was used to convert arachidonic acid into PGE and PGF $_{2 \alpha}$. Although I was inexperienced in working 


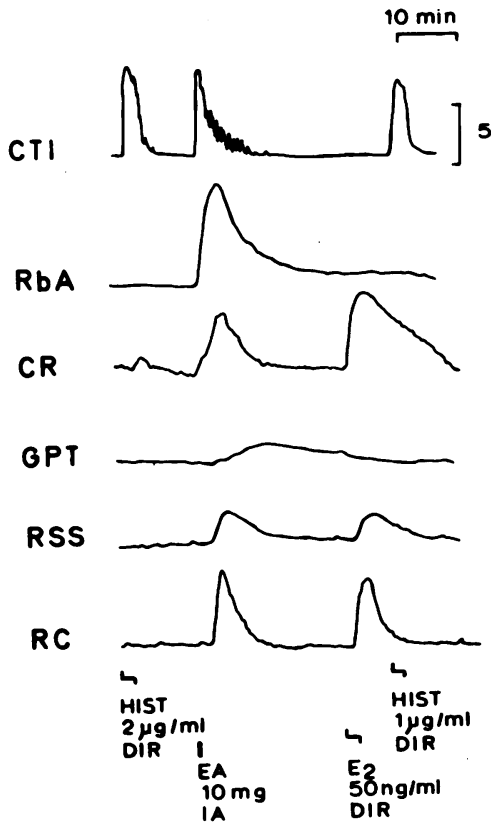

FIG. 6. Release of mediators from isolated lungs of sensitized guineapigs. The lungs were perfused through the pulmonary artery with Krebs' solution and the effluent superfused a cat terminal ileum (CTI), rabbit aorta spiral strip (RbA), chick rectum (CR), guinea pig trachea (GPT), rat stomach strip (RSS) and rat colon (RC). All tissues except CTI were blocked with antagonists to 5HT, catecholamines and histamine. Infusions of histamine $(2 \mu \mathrm{g}$ and $1 \mu \mathrm{g} / \mathrm{ml}$ DIR) and of prostaglandin $E_{2}\left(E_{2}, 50 \mathrm{ng} / \mathrm{ml}\right.$ DIR) directly to the assay tissues demonstrated the selective sensitivity of the assay system. Anaphylaxis was induced in the lungs by injecting ovalbumin intra-arterially (EA $10 \mathrm{mg}$ IA). Contractions of CTI demonstrated release of histamine, $R b A$ release of RCS, GPT release of SRS-A and CR, RSS and RC release of prostaglandins. Time $10 \mathrm{~min}$; vertical scale $5 \mathrm{~cm}$. (Piper and Vane, published in Vane, 1971, reference 163, by permission of the Ciba Foundation). with biochemical techniques, for I have always believed in using whole animals or organs whenever possible, I homogenized some guinea-pig lungs, spun off the cell debris, divided the supernatant into testtubes, added arachidonic acid and measured by bioassay the amounts of $\mathrm{PGE}_{2}$ and $\mathrm{PGF}_{2 \alpha}$ formed. To some of the tubes was added aspirin, indomethacin or morphine. By the end of that day I was convinced that aspirin and indomethacin (but not morphine) strongly inhibited the formation of prostaglandins from arachidonic acid (see Fig. 7).

During the time that $I$ was confirming and extending this first experiment, Ferreira and Moncada (12) began to study the effectts of aspirin and indomethacin on prostaglandin release from the spleen (Fig. 8). Independently of these observations, Smith and Willis were using platelets to measure the effects of aspirin on prostaglandin formation. The results of these three studies were published simultaneously in 1971 (10-12). Vane (10) developed the hypothesis that this biochemical intervention in prostaglandin formation by the aspirin-like drugs is the basis of their therapeutic action.

An explanation of the therapeutic action of aspirin and its congeners had long been sought in terms of inhibition of a specific enzyme or biological function. Although these drugs inhibited a wide variety of enzymic reactions in vitro, no convincing relationship could be established between such inhibition and their known anti-inflammatory, antipyretic and analgesic actions. This was largely because of the high concentrations needed for enzyme inhibition. At the time we discovered that aspirin-like drugs inhibited the biosynthesis of prostaglandins in low concentrations, there was some evidence that the prostaglandins participated in the pathogenesis of inflammation and fever, and this reinforced the suggestion that inhibition of prostaglandin biosynthesis could explain the clinical action of these drugs. In the years

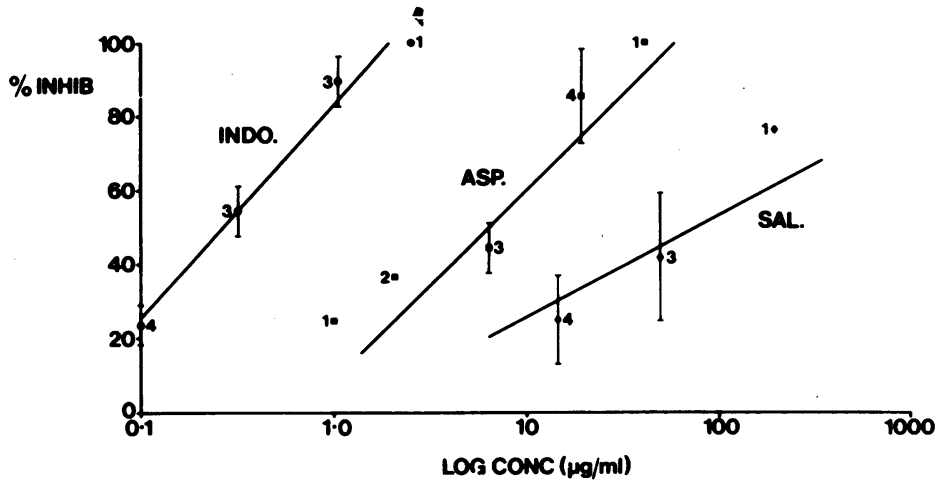

FIG. 7. Concentration $(\mu \mathrm{g} / \mathrm{ml})$ of indomethacin $(\Theta)$, aspirin $(\square)$ and salicylate $(\diamond)$ plotted on a log scale against the percentage inhibition of prostaglandin synthesis (assayed as $\mathbf{P G F}_{2 a}$ on rat colons). The lines are those calculated for best fit. Numbers by points indicate number of experiments. When three or more estimates were averaged, the standard error of the mean is shown. (From Vane, 1971 , reference 10. Reprinted by permission from Nature. Copyright (C) 1971 Macmillan Journals Limited). 


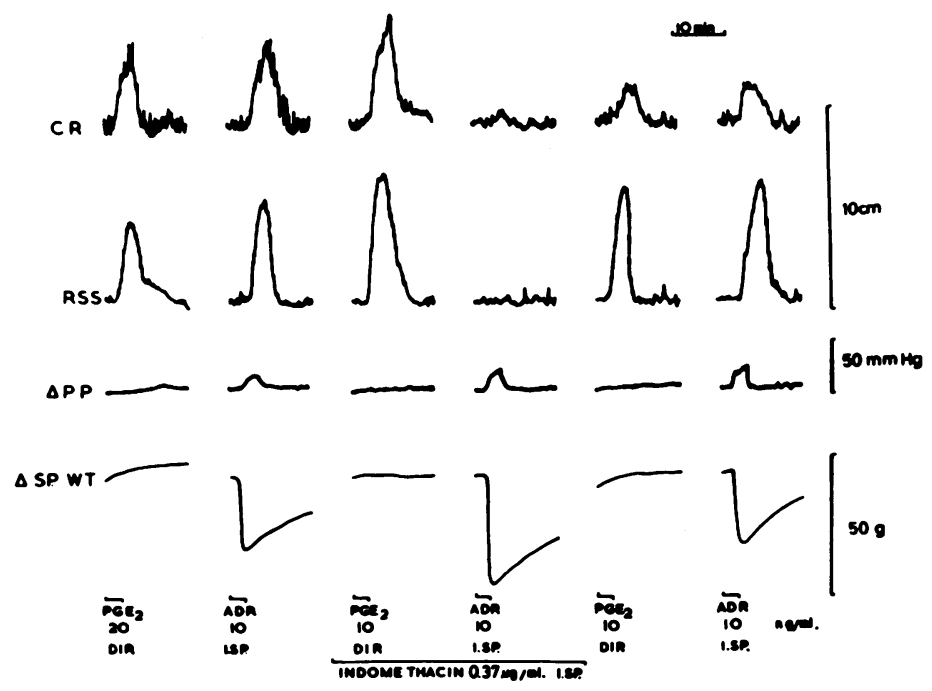

FIG. 8. A spleen from a dog was perfused with Krebs-dextran solution at a rate of $20 \mathrm{ml} / \mathrm{min}$. A continuous sample ( $10 \mathrm{ml} / \mathrm{min})$ of the splenic $\vec{\omega}$ outflow, with antagonists to histamine, 5HT and catecholamines added, was used to superfuse the assay tissues. The figure shows the effects of prostaglandins on a chick rectum (CR; top) and a rat stomach strip (RSS). The next two tracings (bottom) show changes in perfusion pressure $\_$ (PP) and spleen weight (SP.wt.). Except when infused into the spleen indomethacin was added to the splenic outflow to give a concentration of $0.37 \mu \mathrm{g} / \mathrm{ml}$. The first panel shows contractions of CR and RSS induced by prostaglandin $E_{2}(20 \mathrm{ng} / \mathrm{ml}$ DIR $)$. Next an adrenaline infusion into the spleen (ADR $10 \mathrm{ng} / \mathrm{ml}$ ISP) induced a rise in perfusion pressure, a fall in spleen weight and an output of prostaglandins equivalent to $\mathrm{PGE}_{2}$ at about $20 \mathrm{ng} / \mathrm{ml}$. Indomethacin $(0.37 \mu \mathrm{g} / \mathrm{ml})$ was then infused into the spleen. During the next 25 min, the assay tissues relaxed (no 3 shown) and were then more sensitive to $\mathrm{PGE}_{2}(10 \mathrm{ng} / \mathrm{ml} \mathrm{DIR})$. Adrenaline (40 min after start of indomethacin) now caused a greater increase in perfusion pressure, a greater decrease in spleen weight, but no output of prostaglandin. After stopping the indomethacin infusion intothe spleen, the reactivity of the assay tissues gradually decreased and the output of prostaglandin induced by adrenaline infusion into the splenen gradually returned. The adrenaline stimulation shown was made $70 \mathrm{~min}$ after stopping the indomethacin. (From Ferreira, Moncada $\frac{\text { mb }}{2}$ Vane, 1971, reference 12. Reprinted by permission from Nature. Copyright (C) 1971 Macmillan Journals Limited).

which have elapsed since the original observations, a considerable body of evidence has accumulated which supports this hypothesis. Our knowledge about the inflammatory process has also increased, and the way in which prostaglandins participate in this process has been considerably clarified.

Inhibition of prostaglandin biosynthesis is a property peculiar to the aspirin-like drugs, since many otherwise pharmacologically active agents are inactive against this enzyme system, including the opiates, antihistamines, $\alpha$ - and $\beta$-adrenoreceptor blocking agents and antagonists of acetylcholine and 5HT. The anti-inflammatory steroids are also inactive against this enzyme although they can reduce prostaglandin production by inhibition of phospholipase $A_{2}$ (for review see Flower, Blackwell, Di Rosa and Parente, 62).

Any hypothesis which purports to explain the action of a drug in terms of an anti-enzyme action must satisfy at least two basic criteria. First, the free concentrations achieved in plasma during therapy must be sufficient to inhibit the enzyme in question. Second, there must be a reasonable correlation between the level of anti-enzyme activity and the therapeutic potency. Clearly, there is abundant evidence to show that both these criteria are satisfied and there is also good evidence that therapeutic dosage reduces prostaglandin biosynthesis in ma (for review, see Vane, Flower and Salmon, 63).

\section{(3) Prostacyclin}

(a) The advent of the prostaglandin endoperoxides and the discovery of prostacyclin

The isolation by Samuelsson and others of the prostaglandin endoperoxides in the early 1970s was major step forward in prostaglandin research (set. Samuelsson*). The demonstration that the endoper5 oxides caused platelet aggregation and that they were transformed in platelets to $\mathbf{T X A}_{2}$ led us and others to the conclusion that most of the activity associated with RCS was due to TXA $_{2}(64,65)$ (Fig. 9).

From Samuelsson's work we knew that TXA could be released by platelets. We isolated the. enzyme from the 'microsomal' fraction of platelete and showed by our bioassay techniques that endoper oxides, when incubated with this fraction (even 9 $0^{\circ} \mathrm{C}$ ), were rapidly transformed into $\mathrm{TXA}_{2}$ whick potently contracted rabbit aorta and induced platele

*Samuelsson, B. (1983) Lecture to be published in 'Les Prix Nobel 1982', Nobel Foundation (in press). 

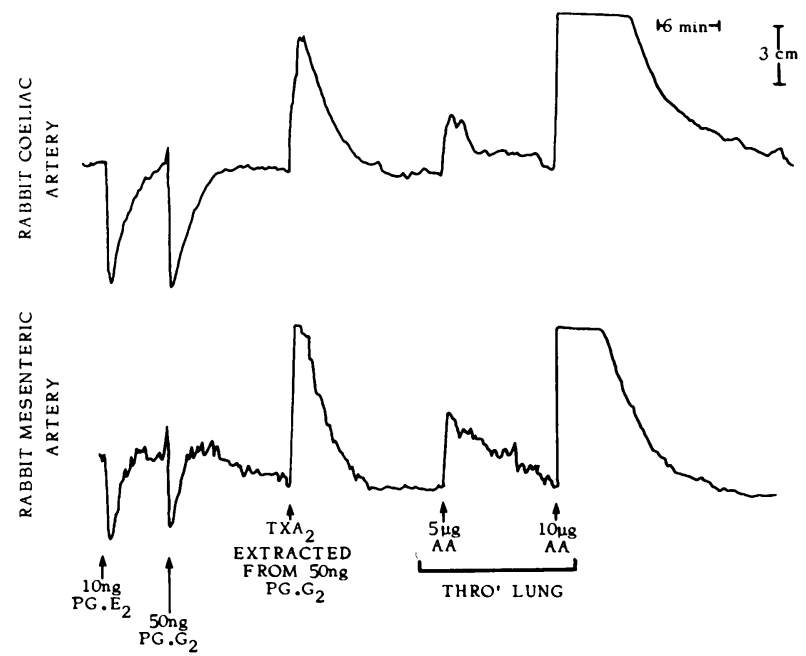

FIG. 9. Rabbit coeliac and mesenteric artery strips were superfused with the outflow of a pair of guinea-pig lungs perfused with Krebs' solution at $10 \mathrm{ml} / \mathrm{min}$. Prostaglandin $\mathrm{E}_{2}(10 \mathrm{ng})$ relaxes the two tissues as does $\mathrm{PGG}_{2}$. Thromboxane $\mathrm{A}_{2}$ generated from $50 \mathrm{ng} P \mathrm{PGG}_{2}$ produced a contraction. Challenge of the lungs with arachidonic acid (AA 5 and $10 \mu \mathrm{g}$ ) produces a dose-dependent release of TXA $\mathrm{A}_{2}$-like material. [From Moncada and Vane, 1977, reference 65, by permission of Academic Press Inc (New York)].

aggregation. This enzyme, which we called 'thromboxane synthetase' $(66,67)$ is now an important therapeutic target for the development of compounds with anti-thrombotic potential.

Moncada, Gryglewski and Bunting then began to look at other tissues to determine whether they also could generate TXA $_{2}$. To do this, they took microsomal fractions of several different tissues and measured, again with the superfusion cascade bioassay, formation of either the classical stable prostaglandins $E_{2}$ and $F_{2 \alpha}$, or of TXA $A_{2}$. It was Moncada's suggestion that we should look into the biosynthetic system of vascular tissue, since vascular endothelium and platelets might share some structural features. Indeed, after several weeks of work we found that microsomal fractions of pig aorta incubated with the endoperoxide did not generate classical prostaglandins even though the endoperoxide activity (measured as RCS) disappeared. We eventually came to the conclusion that the endoperoxide was being transformed into an unknown prostaglandin and began to refer to this substance as PGX. By using recently developed bioassay tissues such as the rabbit coeliac and mesenteric arteries (30) we were able to distinguish between the endoperoxides (which caused a biphasic effect) and PGX (which only relaxed them). Importantly, PGX, in contrast to $\mathbf{T X A}_{2}$, inhibited the clumping of platelets. Like TXA $\mathrm{T}_{2}$, it was also unstable, with a half-life of $2 \mathrm{~min}$ at $37^{\circ} \mathrm{C}$. Boiling the solution for $15 \mathrm{sec}$ destroyed all measured activity.

The first paper on PGX was published by Moncada, Gryglewski, Bunting and Vane in Nature in
October 1976 (16). Although the structure was then unknown, many of the characteristics of PGX were described, together with some important concepts. PGX was different from the other products of PG endoperoxides and its biological activity on isolated tissues, its instability and its potent anti-aggregatory activity, distinguished it from $\mathrm{PGD}_{2}, \mathrm{PGE}_{2}, \mathrm{PGF}_{2 \alpha}$, $\mathrm{TXA}_{2}$ and $\mathrm{TXB}_{2}$. PGX relaxed strips of rabbit mesenteric and coeliac arteries, but contracted rat stomach strip, chick rectum, guinea-pig tracheal chain and guinea-pig ileum, although its contractile potency on these tissues was less than that of the classical prostaglandins. The rat colon was not contracted by PGX: indeed, spontaneous movement was decreased.

In this first paper, the transformation of the PG endoperoxides by platelets to TXA $_{2}$, which caused platelet aggregation and vascular contraction, was contrasted with their transformation by blood vessel microsomes to PGX, which had potent anti-aggregatory properties and relaxed vascular strips. Thus, the concept was suggested that a balance between the amounts of TXA ${ }_{2}$ formed by platelets and PGX formed by blood vessel walls might be critical for thrombus formation. Indeed, in the light of the discovery of this anti-thrombotic property associated with arterial walls, we recalled the pre-Lister vitalistic view that in some way the arteries kept the blood fluid.

We also developed the concept that platelets attempting to stick to vessels may release endoperoxides which are then used by the blood vessel wall to generate PGX, thus limiting or preventing further 


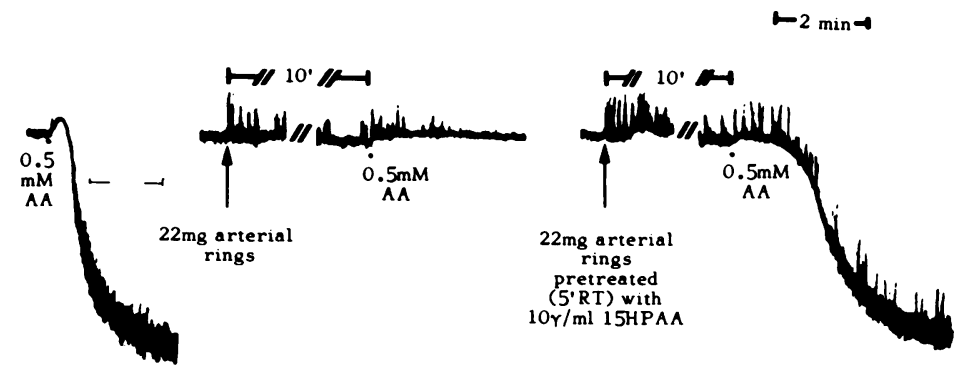

FIG. 10. Inhibition of platelet aggregation by rings of human vascular tissue. Cut rings $(15-30 \mathrm{mg})$, when incubated at $37^{\circ} \mathrm{C}$ in human platele $\vec{D}$ rich plasma (P.R.P.) for $10 \mathrm{~min}$, inhibited the aggregation produced by $0.5 \mathrm{mmol}$ arachidonic acid (AA). When the rings were pretreated by incubation with 15-hydroperoxiarachidonic acid (15-HPAA) $(10 \mu \mathrm{g} / \mathrm{ml})$ for $5 \mathrm{~min}$ at $22^{\circ} \mathrm{C}$, and then added to the P.R.P., aggregation wa $\overrightarrow{\mathrm{f}_{\mathrm{b}}}$ once more observed after addition of $0.5 \mathrm{mmol}$ AA. (From Moncada, Higgs and Vane, 1977, reference 164, by permission of The Lancet)

platelet clumping. We also suggested that plaque formation on the arterial wall could hinder access of plate endoperoxides to the PGX generating system. These important properties and concepts are now well established and developed (for review, see Moncada and Vane, 68).

The structure of PGX was established through a collaborative research programme between scientists at the Upjohn Company in Kalamazoo and The Wellcome Foundation Ltd in Beckenham (19). This also led to the first chemical syntheses of the substance which was renamed prostacyclin $\left(\mathrm{PGI}_{2}\right)$ $(19,69)$.

There is now a plethora of names for prostacyclin. The chemical name is $5-\{(1 S, 3 Z, 5 R, 6 R, 7 R)-7$-hydroxy-6-[(1E,3S)-3-hydroxy-1-octenyl]-2- oxabicyclo[3.3.0]oct-3-ylidene\} pentanoic acid. As a freezedried pharmaceutical preparation, the approved name is Epoprostenol and the trade names are Flolan (Wellcome) and Cyclo-prostin (Upjohn). To maintain consistency in the scientific literature, the trivial name, prostacyclin, should be used whenever possible.

\section{(b) The formation and properties of prostacyclin}

Prostacyclin is the main product of arachidonic acid in all vascular tissues so far tested including those of man (Fig. 10). The ability of the large vessel wall to synthesize prostacyclin is greatest at the intimal surface and progressively decreases toward the adventitia (70). Culture of cells from vessel walls also shows that endothelial cells are the most active producers of prostacyclin $(71,72)$.

Prostaglandin relaxes isolated vascular strips and is a strong hypotensive agent through vasodilation of all vascular beds studied, including the pulmonary and cerebral circulations. (For review, see Moncada and Vane, 73). Several authors have suggested that prostacyclin generation participates in or accounts for functional hyperaemia $(74,75)$.
Prostacyclin is the most potent endogenous inhibi? tor of platelet aggregation yet discovered. This effect is short-lasting in vivo, disappearing within $30 \mathrm{~min} \mathscr{Q}$ cessation of intravenous administration. Prostacyclin disperses platelet aggregates in vitro $(16,76)$ and the circulation of man (77). Moreover, it inhibi是 thrombus formation in models using the carotit artery of the rabbit (76) and the coronary artery of the dog (78), protects against sudden death (though to be due to platelet clumping) induced by intraves nous arachidonic acid in rabbits (79) and inhibitis platelet aggregation in pial venules of the mouse when applied locally (80).

Prostacyclin inhibits platelet aggregation by stim lating adenylate cyclase, leading to an increase cAMP levels in the platelets $(81,82)$. In this respect prostacyclin is much more potent than either $\mathrm{PGE}_{1}$ के $\mathrm{PGD}_{2}$ and its effect is longer-lasting. In contrast $\mathrm{TXA}_{2}$, prostacyclin enhances $\mathrm{Ca}^{2+}$ sequestration i platelet membranes (83). Moreover, inhibitory effect on platelet phospholipase $(84,85)$ and platelet cyclos oxygenase (86) have been described. All these effects are related to its ability to increase cAMP in platelets Prostacyclin, by inhibiting several steps in the activas tion of the arachidonic acid metabolic cascade, exere an overall control of platelet aggregability.

Prostacyclin increases cAMP levels in cells other than platelets (for review, see Moncada, 87) raising the possibility that in these cells a balance with the thromboxane system exerts a similar homeostatio control of cell behaviour to that observed in platelets Thus, the prostacyclin/TXA ${ }_{2}$ system may have wides biological significance in cell regulation. An example is that prostacyclin inhibits white cell adherence tor the vessel wall $(88,89)$ to nylon fibres and to endothelial monolayers in vitro (90). Prostacycliph increases CAMP in the endothelial cell itself, suggesting a negative feedback control for prostacycliy production by the endothelium (91-93).

One of the functional characteristics of the intac vascular endothelium is its non-reactivity to platelets 
clearly, prostacyclin generation could contribute to this thromboresistance. Moreover, prostacyclin inhibits platelet aggregation (platelet-platelet interaction) at much lower concentrations than those needed to inhibit adhesion (platelet-collagen interaction) (94). Thus, prostacyclin may permit platelets to stick to vascular tissue and to interact with it, so allowing platelets to participate in the repair of a damaged vessel wall while at the same time preventing or limiting thrombus formation.

\section{(c) Prostacyclin and cytoprotection}

In addition to its well-known vasodilator and antiaggregating actions, prostacyclin shares with other prostaglandins a 'cytoprotective activity', as yet not clearly defined. This activity has usually been studied on gastric ulcers $(95)$. We have suggested $(68,96)$ that this third property may be important in explaining certain therapeutic effects of prostacyclin. For instance, in models of myocardial infarction, prostacyclin reduces infarct size (97-99), arrhythmias (100), oxygen demand (99) and enzyme release from infarcted areas (101). In sheep, prostacyclin protected the lungs against injury induced by endotoxin (102). There was also a beneficial effect in endotoxin shock in the $\operatorname{dog}(103)$ and cat (104) where prostacyclin improves splanchnic blood flow and reduces the formation and release of lysosomal hydrolases. The effects of hypoxic damage in the cat isolated perfused liver are also substantially reduced by prostacyclin (105). Canine livers can be preserved ex vivo for up to $48 \mathrm{hr}$ and then successfully transplanted using a combination of refrigeration, Sacks' solution and prostacyclin (106).

All these effects could be related to a result obtained recently by Moncada and colleagues (107). The addition to platelets of prostacyclin during their separation from blood and subsequent washing substantially improves their immediate functionality in vitro. In addition, whereas platelets normally are functional for about $6 \mathrm{hr}$, when prepared with the addition of prostacyclin, they remain functional for more than $72 \mathrm{hr}$ (107). This extended viability of platelets in vitro is not accompanied by a prolonged increase in levels of cAMP, thus separating the effect from the classical anti-aggregating activity (108). Interestingly, there has been a study demonstrating a dissociation between anti-aggregating and cytoprotective effects of a prostacyclin analogue in a model of acute myocardial ischaemia (109).

All these results suggest that some of the therapeutic effects of prostacyclin might be related to this cytoprotective effect and point to even wider indications for prostacyclin in cell or tissue preservation in vivo and in vitro.

\section{(d) Prostacyclin and atherosclerosis}

Lipid peroxides, such as 15-hydroperoxy arachidonic acid (15-HPAA), are potent and selective inhibitors of prostacyclin generation by vessel wall microsomes or by fresh vascular tissue (see Fig. 10) $(17,18,110,111)$. There are high concentrations of lipid peroxides in advanced atherosclerotic lesions (112). Lipid peroxidation induced by free radical formation occurs in vitamin E deficiency, the ageing process and perhaps also in hyperlipidaemia accompanying atherosclerosis (113). Accumulation of lipid peroxides in atheromatous plaques could predispose to thrombus formation by inhibiting generation of prostacyclin by the vessel wall without reducing TXA $_{2}$ production by platelets. Moreover, platelet aggregation is reduced by 15-HPAA and this aggregation is not inhibited by adenosine or $\mathrm{PGE}_{1}$ (114). Human atheromatous plaques do not produce prostacyclin $(115,116)$. In normal rabbits the production of prostacyclin by the luminal surface of the aorta is abolished by de-endothelialisation and slowly recovers with re-endothelialisation over a period of about 70 days. However, the recovery of prostacyclin formation did not occur in rabbits made moderately hypercholesterolaemic by diet (117). These results suggest that it would be worth exploring whether attempts to reduce lipid peroxide formation by inhibiting peroxidation influence the development of atherosclerosis and arterial thrombosis. Vitamin E acts as an antioxidant and perhaps its empirical use in arterial disease in the past (118-120) had, in fact, a biochemical rationale. For discussion of the implication of prostacyclin and $\mathbf{T X A}_{2}$ in diseases other than atherosclerosis see Moncada and Vane (68).

\section{(e) Clinical applications of prostacyclin}

Prostacyclin is available as a stable, freeze-dried preparation (Epoprostenol) for administration to man. Intravenous infusion of prostacyclin in healthy volunteers leads to a dose-related inhibition of platelet aggregation, dispersal of circulating platelet aggregates, arteriolar vasodilatation, increases in skin temperature, facial flushing and sometimes headache $(87,121)$. Infusion of prostacyclin into patients susceptible to migraine or cluster headache induces, in most cases, a headache different from those usually experienced (122).

Extracorporeal circulation of blood brings it into contact with artificial surfaces which cannot generate prostacyclin. In the course of such procedures, thrombocytopaenia and loss of platelet haemostatic function occur and make an important contribution to the bleeding problems following charcoal haemoperfusion and prolonged cardiopulmonary bypass in man. Formation of microemboli during cardiopul- 
monary bypass may also contribute to the cerebral complications which sometimes follow this procedure. Platelet damage and thrombocytopaenia were prevented by prostacyclin both in animal models of extracorporeal circulation $(87,121)$ and in man.

In patients with fulminant hepatic failure undergoing charcoal haemoperfusion (123), prostacyclin infusion prevented the fall in platelet count and elevation of $\beta$-thromboglobulin seen in the control patients. Gimson and his colleagues (124) have made almost 200 charcoal haemoperfusions on a daily basis using prostacyclin for platelet protection in the treatment of 76 patients with fulminant hepatic failure. Remarkable survival rates $(65 \%)$ were obtained in the 31 patients who had been referred early and in whom the serial haemoperfusions were started whilst the signs of grade III encephalopathy were still apparent (not rousable but may or may not respond to painful stimuli). The authors thought that this was probably the major factor in the improved survival rate, a reflection of the better biocompatibility of the system because prostacyclin was used, allowing the patients to be treated in an earlier stage. In the group treated later, with Grade IV encephalopathy already present, $20 \%$ survived, so that the overall survival rate from the 76 patients was $38 \%$. These results (especi- ally those treated early) compare favourably withza survival rate of $15 \%$ in patients under standse intensive care measures.

Several double-blind clinical trials of prostacycin in cardiopulmonary bypass have been publisteed (125-131). The treatment groups showed a presergation of platelet number and function, with a redection in the blood loss in the first $\mathbf{1 8} \mathrm{hr}$ after operation. In the trial by Longmore and colleagues (130), 解 blood loss was halved. In that by Walker and workers (129), filters were used and the formation-of platelet aggregates on the filters from the placebo group contrasted strikingly with the lack of platetet adhesion to those from patients treated with proseacyclin (Fig. 11). The heparin-sparing effect of prosincyclin was confirmed and the vasodilator effects werre not troublesome; indeed, Nobak and colleagues (1引y) suggest that these effects may be utilised in contridling intra-bypass hypertension. Clearly, the use $8 \mathrm{f}$ prostacyclin or an analogue should allow improtments in the methodology of extracorporeal circulations.

Therapeutic assessment of prostacyclin is still in its infancy with many trials in progress. The results afe, therefore, still preliminary, but nevertheless they point the way to conditions in which prostacycin
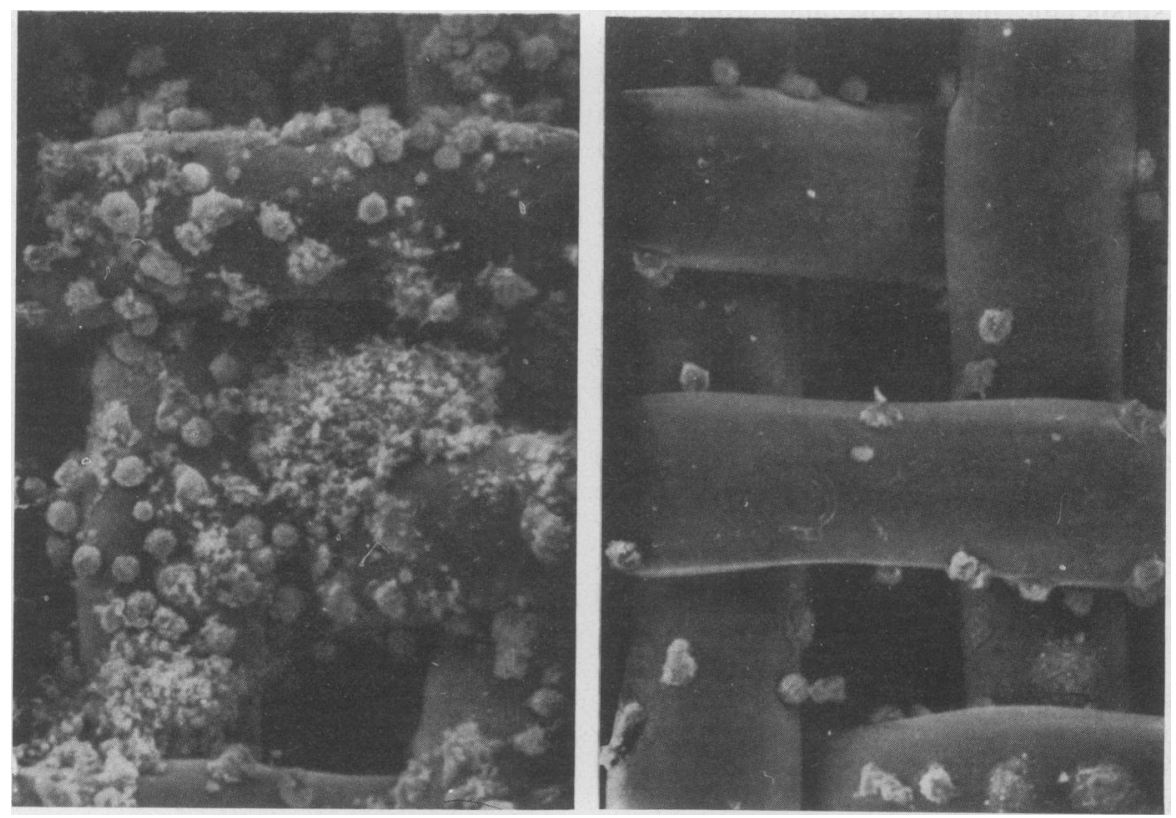

FIG. 11. Filters. Electron micrographs of the downstream face of filters taken from the arterial lines of cardio-pulmonary bypass operationsin man. The left-hand picture (patient receiving placebo) shows formation of platelet aggregates, some clogging the pores $(40 \pm 5 \mu)$ of the filtar. The right hand picture (patient receiving prostacyclin) shows lack of platelet adhesion. The few cells sticking to the filter are leucocytêf. (Electron micrographs kindly provided by Dr N. Read and Mr P. J. Astbury, Wellcome Research Laboratories). 
therapy may be useful. In open trials, prostacyclin was of benefit to patients with peripheral vascular disease both through relief of ischaemic pain and improved ulcer healing (132-137). Placebo-controlled blind trials are now in progress and the results of the first to be analysed (138) are encouraging. In the 13 patients infused intravenously for 4 days with placebo, three showed reduction in rest pain at 5 days, two at 1 month and one at 6 months. After 6 months, three had died and five others had received surgical intervention. Of those 15 patients who were infused with prostacyclin for 4 days (average 7 $\mathrm{ng} / \mathrm{mg} / \mathrm{min}$ i.v.), at 5 days, all had reduction in rest pain. At 1 month, nine still showed a substantial improvement, which was also evident in seven patients at 6 months. By this time, two other patients in the group had received surgical intervention and one had died. Zygulska-Mach and colleagues (139) infused prostacyclin into three patients with sudden blockage of central retinal veins. Improvement was observed in those two patients who were treated within the first $48 \mathrm{hr}$.

Prostacyclin also induces long-lasting improvements in Raynaud's phenomenon. Intravenous infusion of the drug for $72 \mathrm{hr}$ produced striking reductions in the frequency, duration and severity of the disease in 21 of 24 patients. The improvement lasted for a mean of 9-10 weeks and in three patients, subjective improvement was still reported 6 months after the infusion. Pain relief was a striking feature, presumably associated with the increased blood flow as indicated by increased temperature of the hands and fingers (140). Belch and co-workers (141) have also reported successful treatment in four out of five patients and a double-blind clinical trial (142) has now confirmed these results in Raynaud's phenomenon. There was an overall improvement still present at 6 weeks in six of seven patients receiving prostacyclin, but only in one of seven receiving placebo. The prostacyclin patients had a significant fall in the number and duration of attacks over the 6-weeks period post-infusion, whereas there was no change in the placebo group.

Gryglewski and his colleagues in Cracow, who first demonstrated the beneficial effects of infusion of prostacyclin in ischaemic disease of the legs, have now obtained dramatic improvements following prostacyclin infusion in 10 patients with ischaemic stroke (143). Patients with transient ischaemic attacks and haemorrhagic stroke were excluded. With prostacyclin treatment there was a reversal of symptoms strikingly sooner in all 10 patients than could have been expected and in six patients during the first $6-\mathrm{hr}$ infusion. One patient died 2 weeks later of a second stroke, but the other nine have maintained return of function for (so far) up to 6 months.

Prostacyclin has been successfully used in a few cases of pulmonary hypertension and is more effective than PGE $_{1}(144-146)$. Single case studies have suggested that prostacyclin may be useful in the treatment of patent ductus arteriosus (147) and preeclamptic toxaemia (148).

Beneficial effects of intravenous infusion of prostacyclin were obtained in nine patients with severe congestive heart failure refractory to digitalis and diuretics (149). Mean pulmonary and systemic pressures and vascular resistances were reduced and heart rate, cardiac index and stroke index were all increased during the infusion, with facial flushing as the only side effect.

Bergman and colleagues (150) gave an intravenous infusion of prostacyclin to patients with coronary artery disease with no deleterious effects. Heart rate and cardiac index were increased and mean blood pressure, systemic and pulmonary resistance all fell. Mean atrial pacing time to angina rose from 142 to $241 \mathrm{sec}$. They concluded that acute administration of prostacyclin was beneficial in angina, having effects similar to those of the short-acting nitrates. In five patients with coronary artery disease, prostacyclin was safely infused directly into diseased coronary arteries (151) and there was a beneficial effect of intravenous prostacyclin infusions in patients with unstable angina (137). However, prostacyclin had no effect on the number, severity and duration - of ischaemic episodes in eight of nine patients with variant angina, although consistent relief was seen in the ninth patient (152).

A prostacyclin deficiency has been reported in thrombotic thrombocytopaenic purpura (TTP) (153). Infusion of prostacyclin into two patients with TTP did not produce an increase in circulating platelet count $(153,154)$. However, FitzGerald and colleagues (155) have reported an increase in platelet count and an improvement in the neurological status of one such patient during 18 days of prostacyclin infusion. They were sufficiently encouraged to conclude that the controlled evaluation of prostacyclin in TTP was warranted.

Infusion of prostacyclin protects transplanted kidneys from hyperimmune rejection in dogs (156) and in patients with chronic renal transplant rejection (157).

Clearly, there are many clinical conditions which may respond to prostacyclin treatment and its place (or that of chemically stable analogues) in therapeutics will be defined in the next few years. Some of these conditions are pre-eclamptic toxaemia (158), haemolytic uraemic syndrome (159), peptic ulceration (160), the thrombotic complications associated with transplant rejection (156), the prevention of tumour metastasis (161) and the treatment of pulmonary embolism (162). 


\section{Acknowledgments}

Over the years I have had a remarkably talented and productive group of colleagues. The have come from many parts of the world, including Australia (Greg Dusting, Bob Hodge), Belgium (Arnold Herman), Brazil (Sergio Ferreira), Great Britain (Mick Bakhle, Rod Flower, Gerry and Annie Higgs, John Hughes, Robert Lowe, Priscilla Piper, John Salmon, Ivor Williams), Holland (Franz Nijkamp), Honduras (Salvador Moncada), Italy (Domenico Regoli), Poland (Krystyna Herbaczynska-Cedro, Richard Gryglewski, Janina Staszewska-Barczak), Singapore (Kevin $\mathrm{Ng}$ ), and the United States (Jim Aiken, Alan Block, Nobby Gilmore, Jack McGiff, Phil Needleman). Some of these have returned to my laboratory several times. Others have started as technicians and are still with me as $\mathrm{Ph}$.D.s. All (and many others) have contributed to the work which I have described. In particular, the discovery of prostacyclin was made in the Prostaglandin Research Department of The Wellcome Research Laboatories under the direction of Dr Salvador Moncada with the co-operation of Richard Gryglewski and Stuart Bunting. The further pre-clinical development of prostacyclin in our laboratories was also largely directed by Dr Salvador Moncada. I would like to thank all of these friends and colleagues for their help and collaboration over the years. Their participation in the work described in this article is gratefully acknowledged.

I would also like to thank Mrs A. Higgs and Mrs A. Skinner for their help in the preparation of this manuscript.

\section{References}

1. FeldBerG, W. (1967) John Henry Gaddum, Biographical Memoirs of Fellows of the Royal Society, 13, 57.

2. GADDUM, J.H. (1964) In: Drugs in our Society, p. 17. The John Hopkins Press, Baltimore, Maryland.

3. EULER, U.S. VON (1936) Biochimica et biophysica acta, 499, 48.

4. FerReirA, S.H. \& VANE, J.R. (1967) Nature (London), 216, 868.

5. WILlis, A.L. (1969) Journal of Pharmacy and Pharmacology, 21, 126.

6. WILliS, A.L. (1969) In: Prostaglandins, Peptides and Amines, p. 31. Academic Press, New York.

7. HeRbaCzynSKa-CedRo, K. \& VANE, J.R. (1973) Circulation Research, 33, 428.

8. LONIGRO, A.J., ITSKovitz, H.D., Crowshaw, K. \& MCGIFF, J.C. (1973) Circulation Research, 32, 712.

9. Lonigro, A.J., Terragno, N.A., MALIK, K.U. \& MCGiff, J.C. (1973) Prostaglandins, 3, 595.

10. VANE, J.R. (1971) Nature (New Biol), 231, 232.

11. SMITH, J.B. \& Willis, A.L. (1971) Nature (New Biol), 231, 235.

12. Ferreira, S.H., Moncada, S. \& VANe, J.R. (1971) Nature (New Biol), 231, 237.

13. Feldberg, W., GuPta, K.P., Milton, A.S. \& Wendlandt, S. (1973) Journal of Physiology (London), 234, 279.

14. PIPER, P.J. \& VANE, J.R. (1969) Nature (London), 223, 29.

15. Hamberg, M., Svensson, J. \& Samuelsson, B. (1975) Proceedings of the National Academy of Sciences, U.S.A., 72, 2994.

16. Moncada, S., Gryglewski, R.J., Bunting, S. \& VANE, J.R. (1976) Nature (London), 263, 663.

17. GRYglewSKI, R.J., BUNTING, S., MONCADA, S., Flower, R.J. \& VANe, J.R. (1976) Prostaglandins, 12, 685.

18. MonCada, S., GRYglewski, R.J., Bunting, S. \& VANE, J.R. (1976) Prostaglandins, 12, 715.

19. Johnson, R.A., MORTON, D.R., KinNer, J.H., GORMAN, R.R., MCGUIRE, J.R., SUN, F.F., WhITTAKER, N., BUNT ING, S., SAlmon, J., Moncada, S. \& VANe, J.R. (1976) Prostaglandins, 12, 915.

20. Gaddum, J.H. (1959) Pharmacological Reviews, 11, 241.

21. Magnus, R. (1903) Ergebnisse der Physiologie, 2, 637.

22. DALE, H.H. (1912) Journal of Pharmacology and Experimental Therapeutics, 4, 167.

23. GadduM, J.H. (1953) British Journal of Pharmacology and Chemotherapy, 8, 321.
24. Finkleman, B. (1930) Journal of Physiology (London), 70, Z4t5.

25. VANE, J.R. (1964) British Journal of Pharmacology, 23, 36 要

26. PAlmer, M.A., PiPer, P.J. \& VANe, J.R. (1973) British Jouenal of Pharmacology, 49, 226.

27. CollieR, J.G. (1972) British Journal of Pharmacology, 44, $\overrightarrow{\mathrm{t}} 3$

28. FerReIRA, S.H. \& SouzA Costa, F.S. (1976) European Journal of Pharmacology, 39, 379.

29. GRYGLEWSKI, R.J., KORBUT, R. \& OCETKIEWICZ, A.C. (1) Nature (London), 273, 765.

30. Bunting, S., MONCADA, S. \& VANE, J.R. (1976) Brizissh Journal of Pharmacology, 57, 462.

31. Needleman, P., Bronson, S.D., Wyche, A., Sivakoff, Mod\& NiCOLAOU, K.C. (1978) Journal of Clinical Investigation, (11, 839.

32. HoDGE, R.L., LowE, R.D. \& VANE, J.R. (1966) Journat- of Physiology (London), 185, 613.

33. VANE, J.R. (1969) British Journal of Pharmacology, 35, 20

34. Moncada, S., Ferreira, S.H. \& VANE, J.R. (1978)पूn: Advances in Prostaglandin and Thromboxane Research, \$ol. 5, p. 211. Raven Press, New York.

35. PIPER, J., COLlier, H.O. \& VANE, J.R. (1967) Na\}? (London), 213, 838.

36. STASZEWSKA-BARCZAK, J. \& VANE, J.R. (1965) Journafigoj Physiology (London), 177, 57.

37. STASZEWSKA-BARCZAK, J. \& VANE, J.R. (1965) British Jouyłnal of Pharmacology and Chemotherapy, 25, 728.

$\omega$

38. STASZEWSKA-BARCZAK, J. \& VANE, J.R. (1967) British Joufal of Pharmacology and Chemotherapy, 30, 655.

39. ReGoli, D. \& VANE, J.R. (1966) Journal of Physiology, $\overrightarrow{183}$ 513

40. FERREIRA, S.H. \& VANE, J.R. (1967) British Journa雨 of Pharmacology and Chemotherapy, 29, 367.

41. BerRy, H.E., Collier, J.G. \& VANE, J.R. (1970) Cling Science, 39, 349.

42. BAKHLE, Y.S. \& VANE, J.R. (1974) Physiological Revie 1007.

43. Hodge, R.L., NG, K.K.G. \& VANE, J.R. (1967) 商能e (London), 215, 138

44. VANe, J.R. (1966) Pharmacological Reviews, 18, 317.

45. GINN, R.W. \& VANE, J.R. (1968) Nature (London), 219, 7 \$4⿴囗十

46. FerreiRA, S.H. \& VANE, J.R. (1967) British Journa Pharmacology and Chemotherapy, 30, 417.

47. PIPER, P.J., VANE, J.R. \& WYllie, J.H. (1970) Naฏ (London), 225, 600.

48. McGiff, J.C., Terragno, N.A., Strand, J.C., Lee, $\overrightarrow{\text { Pु }}$ LONIGRO, A.J. \& NG, K.K.F. (1969) Nature (London), 23 742.

49. Dusting, G.J., Moncada, S. \& VANE, J.R. (1978) Brit⿱士口犬s $h$ Journal of Pharmacology, 64, 315.

50. MCGUIRE, J.C. \& SUN, F.F. (1978) Archives of Biochemisym and Biophysics, 189, 92.

51. GRYGLEWSKI, R. \& VANE, J.R. (1970) British Journabof Pharmacology, 39, 573.

52. NG, K.K.F. \& VANE, J.R. (1967) Nature (London), 216, 762 .

53. NG, K.K.F. \& VANE, J.R. (1968) Naunyn-Schmiedeberg's. Archiv für Pharmakologie und experimentelle Pathologie $\mathbf{2 5 9}$

54. NG, K.K.F. \& VANE, J.R. (1968) Nature (London), 218, $1 \frac{0}{44 .}$

55. PIPER, P.J. \& VANE, J.R. (1969) In: Prostaglandins, Peptides find Amines, p. 15. Academic Press, London and New Y.ork

56. PIPER, P. \& VANE, J.R. (1971) Annals of the New York Academy of Sciences, 180, 363.

57. LINDSEY, H.E. \& WYLLIE, J.H. (1970) British Journah of Surgery, 57, 738 .

58. DAVIS, B.N., HoRTon, E.W. \& Withrington, P.G. (1963) British Journal of Pharmacology, 32, 127.

59. GilmoRe, N., VANE, J.R. \& WYLliE, J.H. (1969) In: Prostaglandins, Peptides and Amines, p. 21. Academic PfBss London and New York.

60. LiLjestrand, G. (1967) In: Nobel Symposium 2, Prostag dins, Stockholm, p. 107.

\section{0}


61. ANGgARD, E. \& SAmuelsson, B. (1964) Journal of Biological Chemistry, 239, 4097.

62. Flower, R.J., Blackwell, G., Di Rosa, M. \& Parente, L. (1981) In: Mechanisms of Steroid Hormone Action, p. 97. Macmillan Press, London.

63. Vane, J.R., Flower, R.J. \& SAlmon, J.A. (1982) In: Prostaglandins and Related Lipids, Vol. 2, p. 21. Alan R. Liss, Inc., New York.

64. Svensson, J., Hamberg, M. \& Samuelsson, B. (1975) Acta Physiologica Scandinavica, 94, 222.

65. MonCADA, S. \& VANE, J.R. (1977) In: Biochemical Aspects of Prostaglandins and Thromboxanes, p. 155. Academic Press, New York.

66. Needleman, P., Moncada, S., Bunting, S., Vane, J.R., HAMBERG, M. \& SAMUElSSON, B. (1976) Nature (London), 261, 558 .

67. Moncada, S., Needleman, P., Bunting, S. \& Vane, J.R. (1976) Prostaglandins, 12, 323.

68. MONCADA, S. \& VANE, J.R. (1983) Harvard Medical School Bicentennial Celebration Proceedings. John Wiley (in press).

69. WhitTAKER, N. (1977) Tetrahedron Letters No. 32, 2805.

70. Moncada, S., Herman, A.G., Higgs, E.A. \& VANe, J.R. (1977) Thrombosis Research, 11, 323.

71. WEKSLER, B.B., MARCUS, A.J. \& JAFFE, E.A. (1977) Proceedings of the National Academy of Science, U.S.A., 74, 3922.

72. Macintyre, D.E., Pearson, J.D. \& GoRdon, J.L. (1978) Nature (London), 271, 549.

73. Moncada, S. \& VANE, J.R. (1979) Pharmacological Reviews, 30, 293.

74. Whittle, B.J.R. (1980) In: Gastro-intestinal Mucosal Blood Flow, p. 180. Churchill Livingstone, Edinburgh, London.

75. Axelrod, L. \& LeVine, L. (1981) Diabetes, 30, 163.

76. Ubatuba, F.B., Moncada, S. \& VANe, J.R. (1979) Thrombosis et diathesis haemorrhagica, 41, 425.

77. SzCZEKLiK, A., GryglewsKi, R.J., NizankowSKi, R., MUSiAl, J., Pieton, R. \& Mruk, J. (1978) Pharmacological Research Communications, 10, 545.

78. Aiken, J.W., Gorman, R.R. \& Shebuski, R.J. (1979) Prostaglandins, 17, 483.

79. BAYER, B.-L., Blass, K.E. \& Forster, W. (1979) British Journal of Pharmacology, 66, 10.

80. Rosenblum, W.I. \& El Sabban, F. (1979) Stroke, 10, 399.

81. Gorman, R.R., Bunting, S. \& Miller, O.V. (1977) Prostaglandins, 13, 377.

82. Tateson, J.E., Moncada, S. \& Vane, J.R. (1977) Prostaglandins, 13, 389.

83. Kaser-Glanzmann, R., Jakabova, M., George, J. \& LUSCHER, E. (1977) Biochimica et biophysica acta, 466, 429.

84. Lapetina, E.G., Schmitges, C.J., ChandRabose, K. \& CuATreCASAS, P. (1977) Biochemical and Biophysical Research Communications, 76, 828.

85. Minkes, M., Stanford, M., Chi, M., Roth, G., Raz, A., Needleman, P. \& Majerus, P. (1977) Journal of Clinical Investigation, 59, 449.

86. Malmsten, C., Granström, E. \& Samuelsson, B. (1976) Biochemical and Biophysical Research Communications, 68 , 569.

87. MonCADa, S. (1982) British Journal of Pharmacology, 76, 3.

88. Higgs, G.A., MonCADA, S. \& VANE, J.R. (1978) Journal of Physiology (London), 280, 55.

89. Higgs, G.A. (1982) In: Cardiovascular Pharmacology of the Prostaglandins, p. 315. Raven Press, New York.

90. BoXer, L.A., Allen, J.M., SChMidt, M., Yoder, M. \& BAEHNER, R.L. (1980) Journal of Laboratory and Clinical Medicine, 95, 672 .

91. HoPKINS, N.K. \& GORMAN, R.R. (1981) Journal of Clinical Investigation, 67, 540 .

92. Schafer, A.I., Gimbrone, M.A. JR \& HANDIN, R.I. (1980) Biochemical and Biophysical Research Communications, 96, 1640.
93. Brotherton,. A.A.F. \& HoAK, J.C. (1982) Proceedings of the National Academy of Sciences, U.S.A., 79, 495.

94. HiggS, E.A., Moncada, S., VANE, J.R., CAEN, J.P., Michel, H. \& Tobelem, G. (1978) Prostaglandins, 16, 17.

95. WhitTLE, B.J.R. (1980) Brain Research Bulletin, 5 (Suppl. 1), 7.

96. VANE, J.R. (1983) In: Advances in Prostaglandin, Thromboxane and Leukotriene Research, Vol 11, p. 449. Raven Press, New York.

97. JuGDUTT, B.F., HuTCHINS, G.M., BULKLEY, B.H. \& BECKER, L.C. (1979) Clinical Research, 27, 177A.

98. OGletree, M.L., Lefer, A.M., SMith, J.B. \& Nicolaou, K.C. (1979) European Journal of Pharmacology, 56, 95.

99. Ribeiro, L.G.T., Brandon, T.A., HopkinS, D.G., Reduto, L.A., TAYlOR, A.A. \& Miller, R.R. (1981) American Journal of Cardiology, 47, 835.

100. Starnes, V.A., Primm, R.K., Woolsey, R.L., OATES, J.A. \& Hammon, J.W. (1982) Journal of Cardiovascular Pharmacol ogy, 4, 765 .

101. Ohlendorf, R., Perzborn, E. \& Schror, K. (1980) Thrombosis Research, 19, 447.

102. Demling, R.H., Smith, M., Gunther, R., Gee, M. \& FlynN, J. (1981) Surgery, 89, 257.

103. Fletcher, J.R. \& RAmwell, P.W. (1980) Circulatory Shock, 7, 299.

104. Lefer, A.M., TABas, J. \& SMIth, E.F. III (1980) Pharmacology, 21, 206.

105. ARAKI, H. \& LeFER, A.M. (1980) American Journal of Physiology, 238, H176.

106. MONDEN, M. \& FORTNER, J.G. (1982) Annals of Surgery, 196, 38.

107. Moncada, S., Radomski, M. \& VARGaS, J.R. (1982) British Journal of Pharmacology, 75, 165P.

108. Blackwell, G.J., Radomski, M., Vargas, J.R. \& MonCADA, S. (1982) Biochimica et biophysica acta, 718, 60.

109. SCHROR, K., OHLENDORF, R. \& DARIUS, H. (1981) Journal of Pharmacology and Experimental Therapeutics, 219, 243.

110. Bunting, S., Gryglewski, R., Moncada, S. \& VANe, J.R. (1976) Prostaglandins, 12, 897.

111. Salmon, J.A., Smith, D.R., Flower, R.J., Moncada, S. \& VANE, J.R. (1978) Biochimica et biophysica acta, 523, 250.

112. Glavind, J., Hartmann, S., Clemmesen, J., Jessen, K.E. \& DAM, H. (1952) Acta Pathologica et Microbiologica Scandinavica, 30, 1.

113. Slater, T.F. (1972) Free Radical Mechanisms in Tissue Injury. Pion. Ltd., London.

114. Mickel, H.S. \& HoRbar, J. (1974) Lipids, 9, 68.

115. D'Angelo, V., Villa, S., Mysliwiec, M., Donati, M.B. \& De Gaetano, G. (1978) Thrombosis et diathesis haemorrhagica, 39, 535.

116. Sinzinger, H., Feigl, W. \& Silberbauer, K. (1979) Lancet, ii, 469.

117. Eldor, A., Falcone, D.J., HajJar, D.P., Minick, C.R. \& WeKSLER, B.B. (1982) American Journal of Pathology, 107, 186.

118. BoYD, A.M. \& MARKS, J. (1963) Angiology, 14, 198.

119. HAEgER, K. (1968) Vascular Diseases, 5, 199.

120. MARKS, J. (1962) Vitamins and Hormones, 20, 573.

121. VANE, J.R. (1982) Journal of Endocrinology, 95, 3P.

122. Peatfield, R.C., Gawel, M.J. \& Clifford Rose, F. (1981) Headache, 21, 190.

123. Gimson, A.E.S., Hughes, R.D., Mellon, P.J., Woods, H.F., Langley, P.G., Canalese, J., Williams, R. \& Weston, M.J. (1980) Lancet, i, 173

124. Gimson, A.E.S., Braude, S., Mellon, P.J., Canalese, J. \& Williams, R. (1982) Lancet, ii, 681.

125. BenNeTt, J.G., LONGMORE, D.B. \& O'Grady, J. (1981) In: Clinical Pharmacology of Prostacyclin, p. 201. Raven Press. New York.

126. Bunting, S., O'Grady, J., Fabiani, J.-N., Terrier, E., MONCADA, S. \& VANE, J.R. (1981) In: Clinical Pharmacology of Prostacyclin, p. 181. Raven Press, New York. 
127. Chelly, J., Tricot, A., Garcia, A., Boucherie, J.-C., Fabiani, J.-N., PasselecQ, J. \& Dubost, Ch. (1981) In Clinical Pharmacology of Prostacyclin, p. 209. Raven Press, New York.

128. Radegran, K., Egberg, N., \& Papaconstantinou, C. (1982) Scandinavian Journal of Thoracic and Cardiovascular Surgery, 15, 263.

129. Walker, I.D., Davidson, J.F., Faichney, A., Wheatley, D. \& Davidson, K. (1981) In: Clinical Pharmacology of Prostacyclin, p. 195. Raven Press, New York.

130. Longmore, D.B., BenNeTt, J.G., HoYle, P.M., SMITH, M.A., GREGORY, A., OSIVAND, T. \& JoNES, W.A. (1981) Lancet, i, 800.

131. NobaCK, C.R., TINKER, J.H., KAYE, M.P., Holcomb, G.R. \& PluTH, J.R. (1980) Circulation, 62, (Suppl. 3), 1242.

132. NeGUS, D. (1981) In: Hormones and Vascular Disease, p. 181 Pitman Medical.

133. OLSSON, A.G. (1980) Lancet, ii, 1076.

134. PARDY, B.J.H., LeWIS, J.D. \& EASTCOTT, H.H.G. (1980) Surgery, 88, 826.

135. Soreide, O., Segadahl, L., Trippestad, A. \& Engedal, H (1982) Scandinavian Journal of Thoracic and Cardiovascular Surgery, 16, 71.

136. Szczeklik, A., Nizankowski, R., Skawinski, S., Szczeklik, J., GLUSZKO, P. \& GRYGLEWSKI, R.J. (1979) Lancet, i, 1111

137. SzCZeKLIK, A. \& GRYglewski, R. (1981) In: Clinical Pharmacology of Prostacyclin, p. 159. Raven Press, New York.

138. Belch, J.J.F., McKay, A., McArdle, B., Lieberman, P., Pollock, J.G., Lowe, G.D.O., Forbes, C.D. \& Prentice, C.R.M. (1983) Lancet, i, 315.

139. Zygulska-Mach, H. KostKa-TrabKa, E., Niton, A. \& GRYGLEWSKI, R.J. (1980) Lancet, ii, 1075.

140. DowD, P.M., MARTIN, M.F.R., CoOKE, E.D., Bowcock, S.A., JONES, R., DIEPPE, P.A. \& KIRBY, J.D.T. (1982) British Journal of Dermatology, 106, 81 .

141. Belch, J.J.F., Newman, P., Drury, J.K., Capell, H., Lieberman, P., James, W.B., Forbes, C.D. \& Prentice, C.R.M. (1981) Thrombosis and Haemostasis, 45, 255.

142. BelCh, J.J.F., Newman, P., DruRy, J.K., MCKenZie, F., Capell, H., Leiberman, P., Forbes, C.D. \& Prentice, C.R.M. (1983) Lancet, i, 313.

143. Gryglewski, R.J., Nowak, S., Kostka-Trabka, E., BiERON, K., DEMBINSKa-KIEC, A., BlaszCZYK, B., KUSMIDERSKI, J., MARKowSKA, E. \& SZMATOLA, S. (1982) Pharmacological Research Communications, 14, 879.
144. Watkins, W.D., Peterson, M.B., Crone, R.K., Shanno疋 D.C. \& LEVINE, L. (1980) Lancet, i, 1083.

145. Rubin, L.J., Groves, B.M., Reeves, J.T., Frosolono, M. HANDEL, F. \& CATO, A.E. (1982) Circulation, 66, 334.

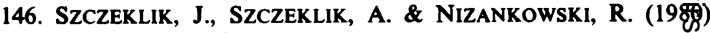
Lancet, ii, 1076.

147. LOCK, J.E., Olley, P.M., CoCEANI, F., SWyer, P.R. \& Ro R.D. (1979) Lancet, i, 1343.

148. FIDLER, J., BENNETT, M.J., DE SwIET, M., Ellis, C. \& LEW⿳亠口冋, P.J. (1980) Lancet, ii, 31.

149. YUI, Y., Nakajima, H., KaWai, C. \& MURAKami, T. (1982) American Journal of Cardiology, 50, 320.

150. Bergman, G., Daly, R. Atkinson, L., Rothman, M Richardson, P.J., JACKSON, G. \& JeWITT, D.E. (1981) Lancet, i, 569.

151. HALL, R.J.C. \& DEWAR, H.A. (1981) Lancet, i, 949.

152. Chierchia, S., Patrono, C., Crea, F., Ciabattoni, G., (De Caterina, R., CinotTi, G.A., Distante, A. \& Maseri $\bar{g}$. (1982) Circulation, 65, 470.

153. Hensby, C.N., Lewis, P.J., Hilgard, P., MufTI, G.J., Hoths, J. \& WEBSTER, J. (1979) Lancet, ii, 748.

154. Budd, G.T., BuKowski, R.M., LuCAS, F.V., Cato, A.E.o\& CocChETTO, D.M. (1980) Lancet, ii, 915.

155. FitzGerald, G.A., RoBERTS, L.J. II., MAAS, D., BRASH, A: \& OATES, J.A. (1981) In: Clinical Pharmacology of Prostatclin, p. 81. Raven Press, New York.

156. MUNDY, A.R., BEWICK, M., MONCADA, S. \& VANE, J.R. (1980) Prostaglandins, 19, 595.

157. Leithner, C., Sinzinger, H. \& SChwarz, M. (1981) Prostarglandins, 22, 783.

158. FidLer, J., ElLIS, C., BenNett, M.J., DE SwIET, M. \& Lewis, P.J. (1981) In: Clinical Pharmacology of Prostacyclin, p. 1前. Raven Press, New York.

159. WebSTER, J., BoRYSIEWICZ, L.K., REES, A.J. \& LEWIS P.J. (1981) In: Clinical Pharmacology of Prostacyclin, D大. Raven Press, New York.

160. Whittle, B.J.R., KauffMan, G.L. \& Moncada, S. 9 Nature (London), 292, 472.

161. HonN, K.V., Cicone, B. \& SKoff, A. (1981) Science, 282 1270.

162. UtsunomiYa, T., Krausz, M.M., Valeri, C.R., Shepro, $\bar{\Phi}$. \& HeChTMAN, H.B. (1980) Surgery, 88, 25.

163. VANE, J.R. (1971) In: Identification of Asthma, p. 121. Churc前11 Livingstone.

164. MONCADA, S., HiggS, E.A. \& VANE, J.R. (1977) Lancet, i, $\overrightarrow{\overline{\phi B}}$ 